\title{
Does Job Orientation Affect the Performance of Employees: Case Study Section of Techniques distribution Local Water Enterprises (PDAM) Balikpapan City
}

\author{
H. Tamzil Yusuf ${ }^{\# 1}$, Imam Arry wibowo ${ }^{\# 2}$ \\ \# Economic Faculty, Balikpapan University \\ Balikpapan, Indonesia \\ 1tamzilyusuf56@gmail.com \\ 2imameuniba-bpn.ac.id
}

\begin{abstract}
Orientation to work is a job for an individual; based on their expectations are embodied in their work. Motivation is about stimulating people to action and to achieve a desired task. For organizations of all sorts to be efficient and successful, enough of every person's drives must be stimulated and satisfied to ensure effective performance. Employees, who have the motivation, orientation, and loyalty high job with a good performance for the company, can improve its service to consumers. Work orientation not only for new employees but for an old employee. Customer services conducted by PDAM Balikpapan city are closely related to performance of employees, especially employees of parts distribution techniques. The PDAM as local companies should provide the best for consumers, by providing the motivation, clear work orientation so as to improve the performance of employees. This research was conducted in order to know whether the motivation, work Orientation and Loyalty Work has influence on Employee Performance Parts The distribution of Techniques in the PDAM Balikpapan city. The results showed, simultaneously the variables Motivation, Work Orientation and Loyalty have a relationship and the influence of to variable of Employee Performance Part of Distribution Techniques the PDAM Balikpapan city, and orientation Partial Work had dominant influence on employee performance part of distribution techniques the PDAM Balikpapan this acceptable and proven because variables that have partially dominant influence on the variable portion of employee performance distribution techniques the PDAM Balikpapan city.
\end{abstract}

Keywords - motivation, orientation and job loyalty, performance, PDAM Balikpapan city.

\section{INTRODUCTION}

Work orientation is seen as a long-term investment of the company's long-term spending. Orientation encourage employees to improve their ability in the work. Learning orientation is the subject of intrinsic interest in a job such as face the challenges of the job [16]. Sustainable orientation will make the employees gain experience and they will be easier to adapt to the situation and field conditions faced in their efforts including improving performance. This shows that the work orientation positive effect on performance. In conjunction with the creation of a positive image of the internal public, parts distribution techniques serve to foster the trust of employees, perform the duties and responsibilities and develop corporate social responsibility, so that will create motivation, orientation and loyalty work in improving employee performance. Trust employee of the company is dominant in the existence of a company.

PDAM Balikpapan as a public company has a fairly large number of employees. It is comparable to the role of PDAM Balikpapan as a public company that handles customer enough so that motivation, orientation and job loyalty to employee performance PDAM Balikpapan affect the continuity of the company. Employees who have the motivation and orientation of a great work and loyalty high job with a good performance for the company so that the company can improve its service to consumers. Parts distribution techniques contribute to improve motivation, orientation and loyalty as well as the performance of employees working for the company.

This research want to find out, Is simultan variable of motivation, orientation and job loyalty effect on the performance of employees and which of the variables of motivation, orientation and loyalty work the dominant influence on the performance of employees engineering parts PDAM distribution in Balikpapan 


\section{LITERATURE REVIEW}

Learning orientation has significant influence with variable intellectual work (working smart), and the intellectual work has a positive influence on the performance of the sales force [16].

According to [3], in general there was no supervision measures had positive effect on the performance of the internal auditors, but supervision measures positive influence on work motivation. The overall results of this study indicate that supervision measures elements of leadership with participatory management style will foster motivation to work especially Intrinsic motivation thus indirectly spur job performance or the performance of internal auditors in performing its duties and functions daily. In other words, the absence of motivation in $\mathrm{f}$ the internal auditor works, the more obstacles to achieve the expected performance. Sunarso [17] had equations that orientation affects the performance of employees.

\section{A. Work Motivation}

Motivation in the management of human resources is shown in general and in particular subordinate. Motivation questioned how to steer the power and potential of subordinates, in order to work together productively managed to achieve and realize the intended purpose. Importance of motivation due cause, distributes, and supports human behavior, so he would work diligently and enthusiastically to achieve optimal results. According to Terry and Rue in [15] says that the motivation was "... getting a person to exert a high degree of effort ..." which means "making one's motivation to work more outstanding". Meanwhile, according to [7], motivation is the process as a first step a person to act due to lack of physical and psychic, or in other words is an impulse that is shown to meet certain goals.

\section{Maslow's Hierarchy of Needs.}

Abraham Maslow is among the most prominent psychologists of the 20th century and the hierarchy of needs, accompanied by the pyramid representing how human needs are ranked, is an image familiar to most business student and managers. Maslow's theory is based on a simple premise: Human beings have needs that are hierarchically ranked. There are some needs that are basic to all human beings, and in their absence, nothing else matters. As we satisfy these basic needs, we start looking to satisfy higherorder needs. Once a lower-level need is satisfied, it no longer serves as a motivator.

The most basic of Maslow's needs are physiological needs. Physiological needs refer to the need for air, food, and water. Imagine being very hungry. At that point, all your behavior may be directed at finding food. Once you eat, though, the search for food ceases and the promise of food no longer serves as a motivator. Once physiological needs are satisfied, people tend to become concerned about safety. Are they safe from danger, pain, or an uncertain future? One level up, social needs refer to the need to bond with other human beings, to be loved, and to form lasting attachments. In fact, having no attachment can negatively affect health and well-being. The satisfaction of social needs makes esteem needs more salient. Esteem needs refer to the desire to be respected by one's peers, feeling important, and being appreciated. Finally, at the highest level of the hierarchy, the need for self-actualization refers to "becoming all you are capable of becoming." This need manifests itself by acquiring new skills, talking on new challenger, and behaving in a way that will lead to the satisfaction of one's life goals.

\section{Two-Factor Theory}

Herzberg, Mausner, and Snyderman [5] approached the question of motivation in a defferent way. By asking indivuals what satisfies them on the job and what dissatisfies them, Herzberg came to the conclusion that aspects of the work environment thas satisfy employees are very different from aspect that dissatisfy them. Herzberg labeled factors causing dissatisfaction of workers as "hygiene" factors because these factors were part of the context in which the job was performed, as opposed to the job itself. Hygiene factors included company policies, supervision, working conditions, salary, safety, and security on the job. To illustrate, imagine that you are working in an unpleasast work environment.

\section{Work Orientation}

According to [7], Work orientation: the concept formed the basis for the harmonious view of industrial relations in the small firm as orientation 
to work was said to cause an individually selfselection to the small firm sector. Meaning: the attitude and behavior of employees, is a concept that can create harmony in the work and that can lead to increased performance of individual employees in a company. Meanwhile, according to [1] orientation to work is the sense of a job for an individual, based on his hope that is embodied in the work.

In general, the employees will feel a little anxious during the first days of work. At least there are three main reasons that caused the nervousness in the the first few days of work [8]:

a. The first reason is that each new situation involving a change and the differences in some cases, will cause the new employees have to face uncertainty.

b. Unrealistic expectations. A new employee often have unrealistically high expectations about the benefits to be obtained in the new job and this is often formed in the fact that they would earn not as they had expected originally.

c. Which can lead to the anxiety a surprise. The surprise may occur if the expectations regarding selfemployment or unfulfilled.

According to [4] said that the program the orientation provided to new employees when they first come to work at least has the objective, among others:

a.To reduce the costs where the orientation is expected to help the new employees to quickly incharge in his work.

b. Alleviate anxiety. Most employees experiencing anxiety when entered into the new work situation. Experience of dealing with these anxieties affect him.

Employees who choose this type of work orientation in choosing where to work, more attention to the atmosphere of work based on strong social relationships. Social relationship is meant here and kerjsama communication that exists between individuals both among employees within the department and between departments, is based on the experts is the reference regarding the orientation of the various ins and outs of employment and background.

\section{Loyalty Work}

According to [12], Human Resource Management is, within Indonesian dictionary describes an attitude is an act and so is based on the establishment, while the work is doing something, or the way employees work in communicating to the leadership or atmosphere of employees feel perushaan.Karyawan the profound pleasure of the work performed. Loyal is dutiful, faithful.

From the above understanding, it can be concluded: Loyalty is a tendency of employees to move to another company. If the employee worked at one company, and the company has provided facilities - adequate facilities and received by its employees, the loyalty of employees of the company will be even greater, then the resulting impulse that causes the employee doing the job becomes even harder. The facilities received by the employee so that the employee will work as well as possible and remain loyal to the company, the company should provide equal remuneration for its employees. It depends on the situation in the enterprise and the objectives to be achieved. For the company argued several ways:

a. Sufficient salary.

b. Provide the spiritual needs of.

c. The occasional necessary create the a relaxed atmosphere.

d. Put the employees in the right position. e. Providing the opportunity the employees to advance.

e. Pay attention a sense of security for the future.

f. Ensuring employees to have loyalty.

g. The occasional invite employees to negotiate.

h. Provide enjoyable facilities.

The indications decline in loyalty and work attitude the employees, among others:

a. Down / low productivity of labor. The fall in labor productivity can be measured or compared with the previous period. Labor productivity drops can occur due to laziness or delay the work.

b. Rising levels of absenteeism. In general, when loyalty and work attitude the employees fell, the employee will be reluctant to come to work every day. When there are symptoms of absenteeism rises must be immediately initiated research

c. A high level of labor migration. Increased the employees turnover is mainly due to displeasure of the the employees working at the company. For that they are trying to find other work as deemed appropriate. A high level of labor migration in addition can reduce work productivity, it can also affect the continuity of the course of the company.

d. Restlessness Loyalty and employee attitudes can lead to decreased anxiety as a leader must know that their restlessness can be manifested in the form of outright lack of work, groaning and other things. 
e. The demands of that often occur. The demands of who actually is a manifestation of and dissatisfaction, which at some stage will cause the nerve to make demands.

f. The strike. The most powerful indication of the rate of the decrease employee loyalty and attitude is a strike. Usually a company that employees already do not feel it anymore until culminated, it will give rise to a claim, and if these demands are not successful, then in general the employees on strike work.

According to [13] that the category of employees of different ages show different accents loyalty such as:

a.Workforce over the age of fifty years show high loyalty to the organization. Possible reasons stand out is that they are already well established in his work, adequate income, allowing them to enjoy a decent standard of living which he considers. Many friends in the organization, a clear pattern of his career, did not want to move, already "too late" start a second career, and in the not too long will retire. In this company there are several permanent employees aged about 50 years and worked long enough in the company, while the contract employees are young.

b. Workers who are in the category forties showed loyalty to careers and professions that had been practiced.

c.Employment in the category of 30-40 years show that loyalty focused on yourself.

d. For those younger than that, have not understood the meaning of loyalty

\section{Performance}

Performance refers to employee performance is measured based on the standards or criteria established companies. Understanding the performance or work performance is defined by Maier [11] as a person's success in carrying out a job. More specifically Lawler and Poter stated that the performance was "role successful achievement" by a man of deeds [9]. From these limits Moh. As'ad concluded that the performance is the results achieved according to the size of a person who applies for the job in question. While according to Russel quoted [2], the resulting performance is the outcome of a particular job function. And according to Smith W. Augt cited by [14] revealed that the performance was "the output drive from the process, human or otherwise.

\section{THE RESEARCH METHODS}

This research is quantitative, in which the data used is primary data is data obtained by conducting research directly to the object of research, PDAM the employees Balikpapan, 80 employees. Secondary data is data who obtained indirectly or through an intermediary medium. In this study, the statistical calculation using regression analysis model with the following equation:

$$
\begin{aligned}
& Y=b o+b_{1} X_{1}+b_{2} X_{2}+b_{3} X_{3} \\
& \text { Remarks : } \\
& \mathrm{Y}=\text { Performance of employees } \\
& \mathrm{X}_{1}=\text { Work Motivation } \\
& \mathrm{X}_{2}=\text { Work Orientation } \\
& \mathrm{X}_{3}=\text { Loyalty Work } \\
& \mathrm{b}_{1}, \mathrm{~b}_{2}, \mathrm{~b}_{3}=\text { Regression Coefficient } \\
& \text { bo } \quad=\text { Constant Coefficients }
\end{aligned}
$$

\section{RESEARCH RESULT}

In these analyzes the techniques used is linear regression to test the hypothesis of simultaneous and partial test. Multiple regression equation results of data processing by using the questionnaire SPSS 20 and $\hat{\mathrm{Y}}=3,745+0,268 \mathrm{X} 1+0,252 \mathrm{X} 2+0,246 \mathrm{X} 3$.

In the multiple linear regression equation calculation above it can be seen the relationship between the dependent variable (Y) with Variables (X1, X2, X3) is constant, it can be seen in a positive regression coefficient means when the $\mathrm{X}$ direction of the change in $\mathrm{Y}$, when changes is negative (-) means the relationship between $\mathrm{X}$ and $\mathrm{Y}$ change in the opposite direction.

TABLE I

RESULTS ANALYSIS

\begin{tabular}{|l|l|l|l|l|l|}
\hline Variable & $\begin{array}{l}\text { Regression } \\
\text { Coefficient }\end{array}$ & $\mathbf{t}_{\text {count }}$ & $\mathbf{t}_{\text {tabel }}$ & $\mathbf{r}_{\text {partial }}$ & Sig \\
\hline Constant & 3,745 & 3,341 & & & 0,001 \\
\hline $\begin{array}{l}\text { Work } \\
\text { Motivation }\end{array}$ & 0,268 & 3,434 & 2,014 & 0,367 & 0,001 \\
\hline $\begin{array}{l}\text { Work } \\
\text { Orientation }\end{array}$ & 0,252 & 3,587 & 2,014 & 0,380 & 0,001 \\
\hline $\begin{array}{l}\text { Loyalty } \\
\text { Work }\end{array}$ & 0,246 & 2,507 & 2,014 & 0,276 & 0,001 \\
\hline & $\begin{array}{l}\text { Multiple R } \\
19,474\end{array}$ & 0,659 & F-hitung \\
\hline & $\begin{array}{l}\text { R.Square } \\
0,000\end{array}$ \\
\hline & $\begin{array}{l}\text { Adjusted R Square } \\
\text { 2,108 }\end{array}$ \\
\hline
\end{tabular}


The values obtained from the equation by a constant coefficient $=3.745$; meaning that when all variables bebes (independent) variable work motivation (X1), Work Orientation (X2) and Loyalty Work (X3) is constant or zero, then the variable Employee Performance (Y) In PDAM Balikpapan rose by 3.745 .

Variable relationship work motivation (X1) on employee performance (Y) PDAM Balikpapan look at the value of regression coefficient $(\mathrm{b} 1)=0.268$; This value indicates if the increase in work motivation variable (X1) of the unit will affect changes to the variable Employee Performance (Y) PDAM Balikpapan at 0.268; Work orientation assuming variable (X2) and Loyalty Work (X3) is constant or equal to zero.

Work Orientation Relationship variables (X2) on employee performance (Y) PDAM Balikpapan look at the regression coefficient value $(\mathrm{b} 2)=0.252$; where the regression coefficients (b2) also shows when the variable Work Orientation (X2) changes by one unit will change the value of the variable employee performance (Y)) amounted to 0.252 Balikpapan City taps assuming variable work motivation (X1) and Variable Working Loyalty (X3) is constant or equal to zero.

Loyalty Variable Employment Relations (X3) on employee performance (Y) PDAM Balikpapan look at the regression coefficient value $(\mathrm{b} 3)=0.246$; where the regression coefficient (b3) is also shown at the time of Variable Working Loyalty (X3) changes by one unit will change the value of variable the performance of employees (Y)) PDAM Balikpapan at 0.246 with the assumption that the variable work motivation (X1) and Loyalty Work (X3 ) is constant or equal to zero.

Simultaneous test or F-test (Fisher-Test) is a test together to test the effect of variable sigifikansi work motivation (X1), Work Orientation (X2) and Loyalty Work (X3) together have an influence on the performance of employees variable (Y ). F test is done by comparing Fcount with Ftable.

In summary the regression results shown in Table 5.3 above, the value of $\mathrm{R}=0.659$ means there is a strong positive correlation between the Effect of Work Motivation, Work orientation, loyalty Work To Performance Officer and have a correlation of $65.9 \%$, while the remaining $34.1 \%$ influenced by other factors. From these results the coefficient of determination (R2) of 0.435 this means that all independent variables that work motivation (X1) Work Orientation (X2) Loyalty Work (X3) have together contributed $43.5 \%$ to the dependent variable (Y) namely the employee's performance. The remaining portion of $56.5 \%$ is influenced by other factors that are not rigorous in this study.

Based on the summary of the results of multiple regression indicated that Fcount of 19.474, while the results in the table Ftable distribution with an error rate of $5 \%$ is equal to 2,725 . This means that Fcount> Ftable (19.474> 2.725). The calculations showed that the variables work motivation (X1) Work Orientation (X2) and Loyalty Work (X3) together have positive and significant influence on the performance of employees variable (Y). The authors conclude first hypothesis in this study which states that the independent variables consist of work motivation (X1) Work Orientation (X2) and Loyalty Work (X3) jointly and simultaneously positive and significant impact on employee performance $(\mathrm{Y})$ proven and acceptable.

This partial testing to see how far the influence separately of each independent variable $(\mathrm{X})$ on the dependent variable $(\mathrm{Y})$ based on the regression results listed in Table 5:10 t test was done by comparing $t_{\text {count }}$ with ttabel with an error rate of $5 \%$ which is equal to 2.014. If $t_{\text {count }}>t_{\text {table }}$ we can conclude these variables have a significant influence.

\section{1) Variable Work Motivation (X1)}

$t_{\text {count }}$ for this variable by 3,434 . Meanwhile the distribution of values in table $5 \%$ of 2.014 . Then $t_{\text {count }}(3.434)>t_{\text {table }}(2.014)$ with a partial value of 0.367 . This means that the variable work motivation (X1) has a positive influence. It is also reinforced with a significance value $(0.000<0.050)$ means variable work motivation (X1) positive and significant impact on employee performance.

\section{2) Variable Work Orientation (X2):}

$\mathrm{t}_{\text {count }}$ for this variable by 3,587. meanwhile the distribution of values in table $5 \%$ of 2.014 . Then $t_{\text {count }}(3.587)>t_{\text {table }}(2.014)$ with a partial value of 0.380 . This means that the variable 
Work Orientation (X2) has a positive influence. It is also strengthened by the significant value $(0,000<0,050)$ Work orientation means variable $(\mathrm{X} 2)$ positive and significant impact on employee performance.

\section{3) Variable Loyalty Work (X3):}

$\mathrm{t}_{\text {count }}$ for this variable by 2.507 . Meanwhile the value of the distribution table $5 \%$ of 2.014 . Then $t_{\text {count }}(2.507)>t$ table $(2.014)$ with a partial value of 0.276 . This means that the variable Work Loyalty (X3) has a positive influence. It is also reinforced with a significance value $(0.011<0.050)$ Working Loyalty means variable (X3) positive and significant impact on employee performance.

Based on the results of the test above it can be concluded that the dominant variable affecting employee performance is variable Work Orientation (X2) with the greatest $t_{\text {count }}(3,587)$, with a significance of 0.001 who is smaller than the value of the error rate of 0.050 . Thus the second hypothesis in this study stated that the Work Orientation variables (X2) is the dominant variable influence on employee performance is proven and can be accepted.

80 respondents, the majority of the male gender that is 78 people or $97.5 \%$, and the rest are female the respondents who as many as 2 people or $2.5 \%$. Age grouping labeled with the age group 1 (20-34 years) who the result there are 11 people or $13.75 \%$. 2 age group (35-50 years) as many as 61 people or $76.25 \% .3$ age groups (> 51 years) as many as 8 people or $10 \%$.

The employees who primary school education as much as 3 people or $3.75 \%$, junior high school education as much as 4 or $5 \%$, educated SMA / SMK many as 64 people or $80 \%$, educated D1 / D3 as many as 6 people or $7.5 \%$ and as many educated S1 3 people, or $3.75 \%$.

\section{CONCLUSIONS}

Variable motivation, orientation and loyalty work simultaneously have a positive relationship and a significant influence on employee performance. Of the two variables that affect the performance of employees, the dominant variable is a work orientation.

Variable work orientation should be maintained and developed a better understanding of the gift to the employees in accordance with their performance because it has a great influence on the productivity of employees of PDAM distribution techniques Balikpapan, while the variable motivation and loyalty of work should be further enhanced its position for employees to the variable is not only a complement of the management process of a company.

The need for periodic assessment process on employee performance as a measure of work orientation that is right for employees.

Needed to do internal the research further by the PDAM Distribution Techniques Balikpapan in terms of the review will increase or maintain the level of employee productivity at a level in line with expectations the company to support the company in achieving its goals. And do not rule out the possibility the company to be able to open up reviewing studies from external parties under review increased productivity of these employees.

\section{REFERENCES}

[1] Ab.Azis Yusof, (2005). Perubahan dan Kepimpinan. Sintok: Universiti Utara Malaysia. hal: 119

[2] Bernadin and Lardoso Faustino Gomes (2000). Manajemen Sumber Daya Manusia, Penerbit Andi, Yogyakarta.

[3] Chandra, Kris Ferdinand. (2006). Pengaruh Tindakan Supervisi terhadap Kinerja Auditor Internal dengan Motivasi Kerja sebagai Variabel Intervening (Studi Empiris Pada PT. Bank ABC). Tesis Program Studi Magister Sains Akuntansi Universitas Diponegoro.

[4] Dessler (2003). Manajemen Sumber Daya Manusia, (terj.) oleh. Benyamin Molan, (Jakarta: Prenhallindo, 1998), hal: 234

[5] Herzberg, F., Mausner, B., \& Snyderman, B. (1959). The motivation to work. New York.

[6] Herzberg, F. (1965). The motivation to work among Finnish supervisors. Personnel Psychology, 18, 393-402.

[7] Ingham, G. 1970. Size of Industrial Organization and Worker Behavior. Cambridge: Cambridge University Press.

[8] Louis, M. R. (1980). Surprise and sense making: What newcomers experience in entering unfamiliar organizational settings. Administrative science quarterly, 226-251.

[9] Luthans (2006). Organizational Behavior (ldh Ed). New York: McGrawHill, pp. 283

[10] Maslow, A. H. (1943). A theory of human motivation. Psychological Review, 50, 370-396; Motivation and personality. New York: Harper.

[11] Moh As'ad, (2003). Psikologi Industri. Yogyakarta: Liberty

[12] Poerwadarminta, W.J.S. (2003). Kamus Umum Bahasa Indonesia. Jakarta: Balai Pustaka.

[13] S.Alex Nitisemito (1991). Manajemen Personalia: Manajemen Sumber Daya Manusia. Jakarta: Ghalia Indonesia, 170-171

[14] Sedarmayanti (2001). Sumber Daya Manusia Dan Produktivitas Kerja. Bandung: Mandar Maju.

[15] Suharto dan Budi Cahyono, (2005). Pengaruh Budaya Organisasi, Kepemimpinan dan Motivasi Kerja Terhadap Kinerja Sumber Daya 
Manusia, di Sekretariat DPRD Propinsi Jawa Tengah, JRBI. Volume 1, Nomor 1, hal 13-30.

[16] Sujan. H, Barton. A.Weitz and Nirmalya Kumar (1994 ) “ Learning Orientation , Working Smart and Effective Selling “, Journal of Marketing, Vol.58, 39-52
[17] Sunarso, Y. (2007). PENGARUH ORIENTASI PEMBELAJARAN, KERJA CERDAS DAN KERJA KERAS DALAM MENINGKATKAN KINERJA TENAGA PENJUAL (Studi Kasus: Pada PT. Infomedia Nusantara Jakarta) (Doctoral dissertation, program Pascasarjana Universitas Diponegoro). 